\title{
Lexical Devices in Political Speech \\ (A Study on Gorontalo Mayoral Election 2018)
}

\author{
SRI WIDYARTI ALI \\ Universitas Negeri Gorontalo \\ widyartiali@ung.ac.id
}

\begin{abstract}
The use of language in political campaign speech is always interesting to be observed. It mostly contains language features which are intended to convince or persuade people to vote someone into power. Therefore, the language used in political speech has always attracted linguist' attention to conduct the study of political discourse. This study is aimed to identify and analyze the lexical devices in political campaign speech delivered by the politicians in Gorontalo mayoral election 2018. The data of the lexical cohessive devices are analyzed based on the theory of lexical cohesion proposed by Halliday and Hasan in 1976. Halliday and Hasan have divided the lexical cohesion into two types; reiteration and collocation. Furthermore, the reiteration has four sub-types; repetition, synonym/near synonym, superordinate, and general word. The data identification reveals that the reiteration and the collocation are both found in the speeches. They are succesfully used as the tools to deliver the speakers purposes and intentions. Hopefully, this study gives more knowledge and insight to others, especially to the language learners, about how the lexical devices are used in political speeches, and more importantly about how language plays its roles to make people get convinced and persuaded.
\end{abstract}

Keywords: lexical cohesion; political speech; campaign

\section{INTRODUCTION}

It is a social phenomenon that language plays a very important role in human lives. Language is needed to fulfil people's needs. When they want to tell or express something to other, they need language whether in form of verbal or non verbal language, or in written or spoken forms. All the way of how people communicate to each other is called language. Language is also used for many different purposes, such as to share ideas, to express feelings, to ask help, to convice or even to persuade others. Through language, people can easily get new information from all over the world, and it can also make people easily communicate with others either in direct or in indirect communication such as through letter or social media. It is the reason why language can not be separated from people's lives.

In politics, language is used for unique purposes and functions. In a speech of a campaign, for example, language is mainly used for convincing or persuading audience to vote someone into power. That's why, every word that a politician chooses must match his needs or intentions in order the audience can easily get the points and trust him. The words they choose or the way they express themselves determine who they are and whether or not they will succeed in their profession. It is why arranging sentence to sentence in a campaign speech requires a specific approach, skill, and an awareness of the audience. Someone who delivers speech must consider who his listeners are and what their backgrounds are, so he can choose and use diction properly in his speech. Being clear about whom the speech is addressed is obviously a key to a successful communication. Therefore, language is regarded 
as the "tool" of politics, and the use of language in politics is also regarded as political discourse.

The important roles performed by language in political field have attracted the attention of linguists to study more and deeper about language in politics. Taiwo (2009) observes that 'the study of language of politics has been carried out within the framework of political rhetoric, linguistic-stylistic, pragmatics, discourse analysis and critical discourse analysis'. These studies commonly explore the deep and comprehensive usage of linguistic features in political spechees. For a linguist, it is obviously interesting to conduct such a challenging study, because language of politics is different with language of other fields. It contains a power to make other people believe. As Beard (2002) affirms that 'looking at the language of politics as an occupation is important because it helps us to understand how language is used by those who wish to gain power, those who wish to exercise power and those who wish to keep power'. It is also the reason of why this study is conducted.

This study observes the language used by politicians in Gorontalo mayoral election in 2018. It specificcaly studies about how the lexical devices are choosen and used to express the politician's thoughts and ideas in convincing his or her audience. Because the focus of study is the campaign speech, certainly every word choosen is intended to persuade the audience and make them believe that all what are expressed in the speech are true and believable. This study explores the words used by the politician by using the theory of discourse analysis about lexical cohesive devices proposed by Halliday and Hassan (1976) that divides the lexical devices into two main types: reiteration and collocation. Furtherly, the reiteration covers four sub-types, they are repetition, synonym or near-synonym, superordinate, and general word. Hopefully, this study will give more knowledge and insight to others, especially to the language learners, about how the lexical devices are used in political speeches, and more importantly about how language plays its roles to make people get convinced and persuaded.

\section{LITERATURE REVIEW DISCOURSE ANALYSIS}

Discourse analysis is generally defined as the analysis of language 'beyond the sentence'. It observes the context of a text in order to understand how linguistic units such word, phrase, clause, or sentences are used, and how they affect the meaning of the text. The discourse analysis definitions given by linguists are varied due to their various theories and analytical purposes. Van Dijk (1977) argues that discourse includes three dimensions: language use, thought transmission and communication in social context. He also distinguishes simple discourse from complex one. Huang Guo wen (2001) perceives discourse from two angles. At a structural level, discourse is a unit of language above the sentence. If viewed from function, it is language in use. While Harris (1952) thinks of discourse as connected speech. Pike (1954) affirms that discourse is a product of human mutual behavior under social cultural context. Brown and Yule (1983) look on discourse as a process. Those definitions basically indicate the similar opinions that discourse analysis is the study of how language used in communication (either in spoken or written) assume meaning, purpose, and unity for their users. Therefore, the study of discourse analysis is considered as a flourishing are of linguistic study and is recognized as making a valuable contribution to our understanding of how language works. 


\section{COHESION AND COHERENCE}

Cohesion and coherence are two important parts of a discourse analysis. They are essential for aiding the readability and the comprehension of the idea in communication, either spoken or written. Coherence is about the unity of the ideas and cohesion is the unity of the structural elements of text. One way to achieve the understandability in a text is through the use of cohesive devices in it. Halliday and Hasan (1976) believe that cohesion is a necessary though not a sufficient condition for the creation of text. Cohesion is necessary and plays an important part in creating a coherent text. Halliday and Hasan (1976) made no distinction between the concept of cohesion and coherence. According to them, coherence is recognized by the overt presentation of cohesive devices to connect sentences or paragraphs in the text. In other words, if there is cohesion in a text, there is certainly coherence. Consequently, other linguists and researcher came up with different definition about coherence.

According to de Beaugrande and Dressler (1981) cohesion and coherence "are the most obvious standards of textuality". Cohesion refers to the way in which the surface elements of a text, such as lexical or grammatical elements, are connected together to display continuity, while coherence refers to the way in which the continuity of sense is established and sustained. De Beaugrande and Dressler (1981) also state that "a text 'makes sense' because there is a continuity of senses among the knowledge activated by the expressions of the text". In the general sense, coherence is a network of relations which organize and create a text in a meaningful related manner. Cohesion is seen as the network of surface relations that link words and expressions to other words and expressions, whereas coherence is the network of conceptual relations which underlie the surface text. In the case of cohesion, stretches of language are connected to each other by virtue of lexical and grammatical dependencies, while in the case of coherence; they are connected by virtue of conceptual or meaning dependencies as perceived by language users. In the general sense, they both concern the way stretches of language are connected to each other.

The concept of cohesion and coherence are cleary detected in written discourse, because the written discourse can be read clearly, so the devices of cohesion can be easier to be observed. Even though a research takes an analysis of a spoken discourse, but in order to get the evidence, the object must be transform into written discourse. For the analysis of cohesive devices, Halliday has divided cohesion into two forms: grammatical and lexical cohesion. Grammatical cohesion includes devices such as reference, substitution, ellipsis, and conjuction. While lexical cohesive is divided into two major categories; reateration and collocation.

\section{LEXICAL COHESION}

Lexical cohesion was first introduced by Halliday and Hasan in 1976. According to Halliday and Hasan (1976), lexical cohesion is one of the five types of cohesion detailed therein, and its contribution to the meaning of text is provided by the continuity of lexical meaning created by the different groups of related words that run through a text. Nunan (1993, p.28) has the same opinion that Lexical cohesion happens when two words in a text are semantically related in some way; in other words, they are related in terms of their meaning. Futhermore, Crystal (1995, p.118) adds that to study lexicon of English, accordingly, is to study all aspects of the vocabulary of the language.

Halliday and Hasan (1976) classify lexical cohesion into two main groups - reiteration and collocation. Reiteration is a form of lexical cohesion which involves the repetition of lexical items, at one end of the scale; the use of a general word to refer back to a lexical and of a item, at the other end of the scale; and a number of things in between- the use of a 
synonym, near-synonyms, or superordinate. They use this table to explain the lexical cohesion more clearly.

TABLE 1. The Lexical Cohesion

\begin{tabular}{|l|l|l|}
\hline 1 & \multicolumn{2}{|c|}{ Reiteration } \\
\hline & a & Same word (repetition) \\
\hline & b & Synonym or near-synonym \\
\hline & c & Superordinate \\
\hline & d & General word \\
\hline 2 & \multicolumn{2}{|c|}{ collocation } \\
\hline
\end{tabular}

\section{REITERATION}

Reiteration is a form of lexical cohesion which involves the repetition of lexical item, at one end of the scale. Repetition is one kind of reiteration. Lexical items which are already present in the previous sentences are repeated in the following sentence in the text.Repetition is just the simple repetition of a word, within a sentence or a poeticalline, with no particular placement of the words. The most direct form of lexical cohesion is repetition of a lexical item; e.g. bear in sentence Algy met a bear. The bear was bulgy (Halliday, 1985: 310). Here the second occurrence of bear harks back to the first.

Synonym or near synyonym is the second part of reiteration where two or more words with very closely related meaning or same meanings are often intersubstitutable in sentences. Synonym is used to mean 'sameness of meaning' (Palmer, 1981,p.88). Lexical cohesion results from the choice of a lexical item that is in some sense synonymous with a preceding one; for example sound with noise, cavalary with horses in "He was just wondering which road to take when he was started by a noise from behind him. It was the noise of trotting horses ... He dismounted and led his horse as quickly as he could along the right-hand road. The sound of the cavalarly grew rapidly nearer ...(Halliday, 1985, p.310)".

According to Halliday and Hasan (1976: 278) superordinate is a name for more general class. It is used to refer to a word which has general properties, not the specific one. According to Palmer (1981, p.85), superordinate is term for words that refer to the upper class itself. In contrary, term for words that refer to the lower class itself is hyponym. For example: Henry's bought himself a new Jaguar. He practically lives in the car (Halliday and Hasan, 1976: 278). Here, car refers back to Jaguar; and the car is a superordinate of Jaguar.

The general words, which correspond to major classes of lexical items, are very commonly used with cohesive force. They are on the borderline between lexical items and substitutes. Not all general words are used cohesively; in fact, only the nouns are when it has the same referent as whatever it is presupposing, and when it is accompanied by a reference item (Halliday and Hasan, 1976: 280-1). For example: There's a boy climbing the old elm. That old thing isn't very safe (Halliday and Hasan, 1976: 280). Here, the reiteration takes the form of a general word thing.

\section{COLLOCATION}

Halliday and Hasan (1976) recognize collocation as an important part of creating cohesion in connected text. They argue the case of collocation as follows: The cohesive effect depends not so much on any systematic relationship as on their tendency to share the same lexical environment, to occur in collocation with one another. In general, any two lexical items having similar patterns of collocation - that is, tending to appear in similar context - will generate a cohesive force if they occur in adjacent sentences (Halliday \& Hasan 1976: 286). 
Collocation is lexical cohesion which depends upon their tendency to co-occur in texts (Firth, 1957 in Lyons, 1977: 612). For example:

A little fat man of Bombay

Was smoking one very hot day.

But a bird called a snipe

Flew away with his pipe,

Which vexed the fat man of Bombay (Halliday, 1985: 312)

There is a strong collocational bond between smoke and pipe, which makes the occurrence of pipe in line 4 cohesive.

Palmer assumes that collocation is very largely determined by meaning and it is sometimes fairly idiosyncratic and cannot easily be predicated in terms of the meaning of the associated words (1981, p. 76). To easier restriction of collocation, he also divides three kinds of collocational restriction. First, some are based wholly on the meaning or the item. Secondly, some are based on range. Thirdly, some restrictions are collocational in the strictest sense (1981, p. 78).

\section{METHOD}

This study applies qualitative method to describe the use of lexical devices in political campaign speech in Mayoral election 2018 that takes place in Gorontalo city. The data are analyzed qualitatively based on the theory of cohesion proposed by Halliday and Hasan in their book entitled Cohesion in English (1976).

This research is located in Gorontalo city where the activities of political campaign speeches take place. In 2018, Gorontalo people had an election of the Mayor that are choosen as the leader of the city. So, during the few months, the politicians did the campaign either in form of verbal or non verbal. In verbal form, the campaign is mostly delivered through speech in front of Gorontalo people as the audience. This research takes the speech as the object of the analysis.

Because this study observes and analyzes the use of lexical devices in political speech, so the data of this research are the sentences where the words, which are indicated as the cohessive devices, are found. While the source of data is the script of the campaign speech delivered by the politicians in Gorontalo mayoral election 2018.

The data are collected through recording the speech during the campaign, then transfom it into written form to make it easy to observe and to find the data of research. The data, which are collected, are in form of sentences or utterances. When the data have been collected, then they are analyzed through three steps. The first is identifying the types of lexical cohesion. This proccess involves the use of Halliday and Hasan (1976) theory about the lexical cohesion and its types. Futhermore, the data are classified into the types of lexical cohesion; Reiteration and collocation for the purpose of analysis. The last step is analyzing and interpreting the use of the lexical cohesion and their meanings in the speech. The result of data analysis is presented in findings and discussion.

\section{FINDINGS AND DISCUSSION}

This research is aimed to find out and describe the lexical devices used by politicians in political campaign speech in Gorontalo Mayoral election 2018. The campaigns took place in some areas of Gorontalo city, and the speeches which are taken as the source of data are those which are delivered by the candidates of mayor and vice-mayor of Gorontalo city. There are 3 records of speeches taken as the source of data, and they were transcribed into written forms. The speeches were delivered by 3 couples of candidates; Mr. AD and Mr. HM as the 
first candidate, Mr. MT and Mr. RK as the second candidate, and Mr. RP and Mr. RM as the third candidate.

The data classification and analysis are conducted based on the theory of lexical cohesion proposed by Halliday and Hasan (1976) who have classifed the lexical cohesion into two main groups: reiteration and collocation. Furthermore, the data classification reveals that the three transcriptions of the speeches covers both the reiteration and collocation as the lexical devices used by the candidates in delivering the speeches. The only device which is not found in the reiteration device is the general word. This is because the language used by the candidates is Indonesian language, therefore it is rather difficult to find the general word used in the source of data or even it is not found at all there. Here are the presentation of the data findings and analysis.

\section{REITERATION}

The reiteration in the speeches is indicated through three devices of lexical cohesion; the repetition, the synonym/near synonym, and the superordinate.

\section{REPETITION}

All the speeches frequently repeat some words that specifically related closely to the intention of the candidates' speeches. Most of the repeated words are about the facts or the city problems and the programs that they will do as the future leaders, which are intended to make an emphasis of their aims and intentions to persuade the audience to choose them.

\section{REPETITION IN THE FIRST CANDIDATE'S SPEECH}

The first couple of candidate, Mr. AD and Mr. HM, have mostly made repetition of words. Compared to the other candidates, Mr. AD has many times repeated some words to emphasize his intention and to strengthen his opinions and statements. Some of the words which are repeated in his speech are pemimpin (leader), program (program), hutang (debt), rakyat (people), kebijakan (policy), keluarga (family), Makassar (name of a city in South Sulawesi Indonesia), APBD Regional Development Budget), and 7 program (7 program).

The word "pemimpin" (which means "the leader") is repeated four times in the opening of the speech.

"Kali ini kita akan kembali memilih pemimpin untuk 5 tahun kedepan. Tetapi kalau pemimpin itu adalah milik semua rakyat kota gorontalo semua berhak untuk memiliki pemimpin di lima tahun kedepan. Bukan hanya milik keluarga, milik istri, milik anak,milik adik, itu bukan pemimpin namanya".

This is considered as an effort of the candidate to give an insight to the audience about the definition of a leader to the society. This word is repeated many times to make the audience understand that a real leader must be able to lead and to protect the society, to be fair to them, and to prioritize them. This word is also used as a device to indirectly say to the audience that they are the real leader that will take the society as their priority if they are elected as the mayor and vice-mayor of Gorontalo city.

Another word repeated in Mr. AD's speech is "program" which means "program. It is also repeated four times in one statement of the opening of the speech.

"Oleh karena itu pada kampanye kali ini, kita harus menawarkan program, dan program ini yaitu program yang lima tahun kedepan, dan masuk di akad bukan program kartu yang lahir dan mati begitu saja”. 
The word "program" is repeated as a way of the candidate to say to the audience about the aim of their campaign, and also to let them know that the program that they offer will give many benefits to the society, as what have been implied in their previous statement, that they will prioritize the society if they are elected. This is considered as the effort of the candidate to persuade the audience.

Other words; rakyat (people), kebijakan (policy), keluarga (family), hutang (debt), Makassar (name of a city in South Sulawesi Indonesia), APBD Regional Development Budget), are also repeated as an emphasis of the problems faced by the presents government, as well as the way of the candidate to offer their future programs and to persuade the audience to trust them and choose them in the election day.

All in all, the repetition of words expressed in the first candidate's speech is aimed to confirm about several things which are basically intended to persuade the audience to trust and to choose them as the mayor and the vice-mayor of Gorontalo city. In the speech, the repetition is used as a device to ensure the audience that they will be good leaders, to reveal to the audience the problems and facts faced by the presents government, and to emphasize the programs that they will do if they are choosen as the mayor and the vice-mayor of Gorontalo city.

\section{REPETITION IN THE SECOND CANDIDATE'S SPEECH}

In the campaign speech delivered by the second candidate, Mr. MT and Mr. RK, the repetition take place in some statements. Some of the repeated words in their speech are bapak ibu (ladies and gentlemen), janji (promise), kepercayaan (trust), and kualitas (quality).

The words bapak ibu are repetead three times in the opening of the speech:

"Bapak dan ibu hadirin yang saya hormati.

"................. Jika bapak ibu sekalian memberikan kepercayaan dan amanat kepada kami untuk menjadi walikota tahun 2019-2024......

"Bapak ibu sekalian, saya sudah membuktikan program-program yang saat ini sudah dirasakan dan dinikmati oleh seluruh warga masyarakat kota Gorontalo"

The repetition of the words Bapak Ibu (ladies and gentlemen) in the speech is aimed to catch the attention of the audience. It is also intended to make an emphasis that the target of the speech is all the women and men who attended there as the audience.

Another repeated word is janji which means "promise". It is repeated three times in the statements:

"Apa yang akan saya sampaikan ini bukan hanya sekedar janji. Bukan hanya sebagai janji. Yang akan saya sampaikan bukan hanya janji yang akan kami utarakan yang akan kami sampaikan pada bapak ibu sekalian tapi saya sudah membuktikan program-program yang saat ini sudah dirasakan dan dinikmati oleh seluruh warga masyarakat kota Gorontalo".

In that statement, the word janji is repeated three times to build a strong belief in the people's mind, that the candidate will not give them a lie. It is used as an effort to ensure the audience about the programs that they have made as the present leaders and later if they are coosen again as the mayor and vice-mayor of Gorontalo city.

The word kepercayaan which means "trust" is repeated twice in the statement:

"Ketika saya diberikan kepercayaan dan amanat lima tahun yang lalu untuk menjalankan apa yang menjadi perintah dari rakyat. Ketika rakyat memberikan kepercayaan kepada saya pada tahun 2013"

The repetition of this word is aimed to remind the audience about the time when they were firstly elected as the mayor and vice-mayor of Gorontalo city, about what the people had expected to them as the leader, and what they had made to fulfill the Gorontalo people's 
expectations. Through the word repetition, the candidate also wants to let the people know that they have never broken their promises as the leader of Gorontalo city, and they will keep doing the good things for Gorontalo.

The last repeated word is kualitas (quality):

"Kalo peningkatan kapasitas dan kualitas berarti menyangkut sarana prasarana dan fasilitas serta sumber daya rumah sakit. Para dokter yang melayani para pasien dan para medis masih sangat kurang, baik dari sisi kualitas, dari jumlah, maupun dari sisi kualitas atau mutu pelayanan bapak dan ibu sekalian masih kurang".

The word kualitas here is repeated three times to clarify the problem faced by the public hospital in Gorontalo city, which directly give effect to the people who stay there as the patients. However, as the present mayor or Gorontalo city, the speaker continues the statement by mentioning some solutions that they have made to overcome the problem of health faced by Gorontalo society.

To sum up, the second candidate's speech contains word repetitions which are intended to get and to emphasize several things. The first is to catch the audience attention, the second is to build a strong belief in the people's mind that the second candidates are the right figure to lead Gorontalo city ahead, the third is to recall the people's mind about what they have made before as the Mayor and vice-Mayor of Gorontalo city, and the fourth is to give a proof about the problems of city and the solutions that they have made for the problems.

\section{REPETITION IN THE THIRD CANDIDATE'S SPEECH}

Similar to the first and the second candidates' speeches, the third candidate also makes repetition of some words in their speech, even though the repetition that they make is not as many as what have been produced by the first and the second candidates. As what a political campaign speech is aimed to, the use of repetition as the cohesive lexical device in their speech is generally intended to persuade the people as audience to trust them and choose them as the mayor and vice-mayor of Gorontalo city.

The repeated words in their speech are perubahan (the change), masyarakat (society), kota Gorontalo (Gorontalo city), rumah sakit (hospital), and anak-anak (childern).

The first repeated word "perubahan" which means "the change" is produced in the opening of the speech. It is mentioned twice in the statement:

"Tentu ini adalah sebuah perubahan yang diharapkan oleh masyarakat. Agar

kota Gorontalo ini ada perubahan yang betul-betul dirasakan oleh masyarakat"

In that statement, the repetition indicates the speaker's thought about the purpose of the people (the audience) to come and to listen to the speech delivered by the candidate; that the people needs a change in Gorontalo city, and they lie their hopes in the third candidate's leadership (later if they are choosen as the Mayor and vice-mayor).

Likewise, the word masyarakat (society) is repeated six times for the same purpose, that is as the way of the candidate to emphasize the people's purpose to come and to listen to their speech, as shown by these statements:

"Tentu ini adalah merupakan sebuah perubahan yang diharapkan oleh masyarakat. Agar kota Gorontalo ini ada perubahan yang betul-betul dirasakan oleh masyarakat. Karena masyarakat ini semuanya ingin mendengarkan program. Masyarakat ingin mendengarkan apa yang akan ditawarkan oleh para calon walikota maupun wakil walikota. Karena masyarakat sudah pernah ikut pemilihan lalu-lalu. Masyarakat butuh program. Masyarakat butuh apa yang akan didapatkan pada saat waalikota dan wakil walikota ini terpilih. Betul ya?". 
The six times repetition of the word masyarakat is intended to strengthen the speaker's opinion about the purpose of the audience to come and to listen to the speech; that they come there with the expectation that the candidate can promise them something good and beneficial for them later if the candidate is succesfully elected as the leaders of Gorontalo city.

Other word repeated in the third candidate's speech is anak-anak which means "children". It is repeated four times in the following statement:

"Bapak ibu sekalian berikut ini kami dengar banyak ibu-ibu yang mengeluh "Pak pendapatan ekonomi kami sudah mulai menurun sementara kami ini harus membiayai kuliah anak-anak kami sekarang sudah mulai sekolah ada juga anakanak kami yang putus sekolah”. makanya kalau kami jadi Walikota maupun Wakil walikota, bukan hanya 500 insya Allah sampai 5000 anak-anak SMA SMK yang mengangur akan kita beri tunjangan agar mereka bisa punya pekerjaan jadi caranya adalah mereka ini dilatih nanti di BLK (Balai Latihan Kerja). Kita akan melatih anak-anak disitu dan mereka akan bisa mendapatkan sertifikat",

The repetition the the word anak-anak (children) presents another fact and problem faced by Gorontalo people. The economic problem lead them to the fact that their children can not have a good education as the preparation for the children's future. By mentioning this words four times, the candidate as the speaker wants to emphasize the problem and also their programs to overcome the problem if they are choosen as the leader of Gorontalo.

In conclusion, the repetition of words produced in the speech of the third candidate have some purposes. The first is to show the speaker's thought and opinion about something, the second is to strengthen the speaker's opinion, the third is to give a clear description and explanation, and the last is to present a fact or a problem in order that it can be known and understood clearly by the audience.

\section{SYNONYM/NEAR SYNONYM}

The second device of reiteration is synonym or near synonym. In the speeches, it is found some synonym of words used by the three speakers from three diferent candidates.

\section{SYNONYM/NEAR-SYNONYM IN THE FIRST CANDIDATE'S SPEECH}

There are seven couples of words idenfied as Synonym/near-synonym in the first candidate's speech. They are transparan-terbuka (opened), merasakan-menikmat (feel/enjoy), tidak bayar-gratis (for free), tingkatkan-naikkan (improveldevelop), mati-meninggal dunia (die), walaupun-tetapi (even though), and rasional-masuk di akal (logical).

The Synonyms and near-synonyms are used in the following statements:

"Pemimpin harus bicara transparan. Harus bicara terbuka dengan rakyat"

"Rakyat harus merasakan dan menikmati APBD"

"Bentor ini tidak bayar. Ini gratis untuk rakyat Gorontalo"

"Kita tingkatkan budget agar mereka semangat. Kita naikkan menjadi Rp.1000.000."

"Ada orang mati, meninggal dunia, dapat Rp. 2.500.000"

"Saya dan Pak H. siap bertarung walaupun, tetapi, pertarungan kami normatif"

"Jadi ini program kerja yang rasional. Yang masuk di akal"

Over all, the use of synonym and near synonym words in the speech is aimed to make a clarification and emphasis about what the speaker has mentioned or said before. As in the data "Pemimpin harus bicara transparan. Harus bicara terbuka dengan rakyat", the word transparan is clarified by the use of the word terbuka in the second sentence. Its purpose is to make the audience understand well about the intention of the speaker. 


\section{SYNONYM/NEAR-SYNONYM IN THE SECOND CANDIDATE'S SPEECH}

The use of synonym and near-synonym is also found in five statements of the second candidate's speech. The synonym and near synonym words in the speech are wujudkkanrealisasikan (make true), kepercayaan-amanat (mandate), dirasakan-dinikmati (feel/enjoy), mutu-kualitas (quality), ahli-spesialis (expert). Here is the list of synonym and near synonym in the speech:

"Program-program yang akan kami wujudkan, kami realisasikan, demi kesejahteraan masyarakat"

"Rakyat memberikan kepercayaan kepada saya pada tahun 2013. Saya jalankan amanat itu dengan rasa tanggung jawab.

"Saya sudah membuktikan program-program yang saat ini sudah dirasakan dan dinikmati oleh masyarakat."

"Dari sisi kualitas atau mutu pelayanan masih kurang pada dokter spesialis".

"Dokter sudah melayani dengan baik, super ahli, super spesialis."

In that speech, the synonym and near-synonym is used as emphasis of a statement, and an effort to give a clear understanding to the audience about something important, like in the data "Program-program yang akan kami wujudkan, kami realisasikan, demi kesejahteraan masyarakat". Itu is also used as a device to emphasize the important point of a statement, such as in the statement "Dokter sudah melayani dengan baik, super ahli, super spesialis" which shows that the doctor who are hired in the hospital are those who have good quality in both education and skill. The word ahli and spesialis clearly indicate it.

\section{SYNONYM/NEAR-SYNONYM IN THE THIRD CANDIDATE'S SPEECH}

In the third candidate's speech, there are only two synonym/near synonym words found. They are menjelekkan-menghujat (to talk bad about someone), and menata-memperbaiki (to revitalize). The statements which contain the synonyms are:

"Ada banyak calon yang informasinya saling menjelekkan, saling menghujat"

"Olehnya kami akan menata ulang kota Gorontalo. Akan memperbaiki kawasan-

kawasan perdagangan".

The use of synonym in the statements show an emphasis of the speaker about something important that he wants to share to the audience. The first statement is intended to emphasize the important part of the sentence Ada banyak calon yang informasinya saling menjelekkan. It is strenghtened by mentioning again the word with another word that has similar meaning saling menghujat. While the second statement is aimed to give a clarification. The word menata ulang is clarified with another word memperbaiki which has similar meaning with it.

\section{SUPERORDINATE}

The superordinate is also one of the cohesive devices found in the speeches. The use of superordinate as a cohesive device, which refers to a name for more general class of word, is found several times in the speeches.

\section{SUPERORDINATE IN THE FIRST CANDIDATE'S SPEECH}

In the first speech, there are only two statements contain the superordinate words.

"Bukan hanya milik keluarga. Milik istri dan anak".

"Ada hutang di rumah sakit. Pemerintah sekarang ada hutang 7,4 miliar di

Aloei Saboe”.

The superordinate in the first statement is the word keluarga which means "family". The word keluarga is the superordinate of istri (wife) and anak (child). In this statement, the 
speaker mentions the superordinate first. The function of using the superordinate word here is to mention the general word first, then clarify it by mentioning the specific words. Likewise, in the second statement, the superordinate or the general word is rumah sakit (hospital). It is the superordinate of the word Aloei Saboe. Aloei Saboe is the name of a hospital in Gorontalo city. So in this statement, the speaker mention the general word first, then come to its specific word.

\section{SUPERORDINATE IN THE SECOND CANDIDATE'S SPEECH}

In the second candidate's speech, there are also two superordinate words found. The statements are:

"Partai politik pengusung mapun pendukung hadir bersama kita pada hari ini.

Dari partai Golkar, Bulan Bintang, Perindo, dan partai Berkarya"

"Saya menggratiskan biaya pendidikan mulai dari uang SPP, uang ujian, uang ijasah, dan lain-lain"

In the first statement, the superordinate is the words partai politic (political party). It refers to the more specific words which are also mentioned in the statement: Golkar, Bulan Bintang, Perindo, Berkarya that represent the name of some political parties in Indonesia. While the second statement provides one superordinate; biaya pendidikan. It is the followed by the more specific words; SPP (monthly fee of students), uang ujian (fee of school examination), and uang ijasah (fee of school certificate). In each statement, the speakers give clarification by mentioning the specific words after mentioning the superordinate words. It shows that there is a good correlation between the first and the second sentences used in the speech.

\section{SUPERORDINATE IN THE THIRD CANDIDATE'S SPEECH}

In the third candidate's speech, there are three statements produced the superordinate. They are:

"Rumah sakit kita sedang terbebani hutang. Kalau baca di koran, 7,5 miliar.

Ini saya baca di halaman depan Gorontalo Post"

"Ada juga anak-anak kami yang putus sekolah, sampai SMA maupun SMK"

"Kampus Gorontalo ada 9. UNG, UG, Ichsan, Poltekkes, Poligon, IAIN,

UMG, Bina Taruna, dan STMIK”

The superordinate in the first statement is the word koran (newspaper). It is then followed by the specific word Gorontalo Post that refers to the name of a newspaper in Gorontalo city. While in the second statement, the superordinate is the word sekolah (school), which is then made specific by the speaker by mentioning the level of school: SMA (Senior High School) and SMK (Vocational School)I. In the last statement, the superordinate is the word kampus Gorontalo (Campus in Gorontalo). The use of this superordinate word is then clarified by the speaker by mentioning the name of nine colleges or universites in Gorontalo city: $U N G, U G$, Ichsan, Poltekkes, Poligon, IAIN, UMG, Bina Taruna, and STMIK.

In conclusion, the use of superordinate in the three speeches has succesfully made the speeches understandable, clear, and well-connected between one sentence to another sentence, or between one text to another text. It means that the cohesive devices are succesfully used by the speakers as the candidates of the mayoral election.

\section{COLLOCATION}

In general, collocation refers to the use of two or some words which have a strong collocational bond or a strong relationship between one to another. The use of collocation as one of the cohesive devices is found in the speeches. 


\section{COLLOCATION IN THE FIRST CANDIDATE'S SPEECH}

The collocation is used twice in the first candidate's speech:

"Para camat, para lurah, ikut kegiatan ini"

"Ada yang namanya jasa untuk dokter, jasa untuk perawat".

The words camat and lurah build a collocation which similarly indicate the position of a leader that lead an area in a city. While the word dokter (doctor) and perawat (nurse) have a strong collocational bond, in which they indicate the name of professions in health field.

\section{COLLOCATION IN THE SECOND CANDIDATE'S SPEECH}

In the second speech, the collocation is only found once in a statement:

"Mereka melakukan aktifitas penjual dan pembeli datang ke pasar...."

The word penjual (seller) is collocated with the word pembeli (buyer), in which they are often used together in one context. These two words often occur together, as where the buyer is, the seller is always there. So, the use of these two words in that statement build a strong collocational bond that make the statement cohesive.

\section{COLLOCATION IN THE THIRD CANDIDATE'S SPEECH}

The collocation is also found in the third candidate's speech. The collocative words are found in the following four statements:

\section{"Mereka punya anggaran kurang lebih 800 sampai 900 Miliyar dan 20\% saja \\ belanja publik" \\ "Dokternya kita akan maksimalkan. Perawatnya akan Maksimalkan 24 jam" \\ "Semuanya sekarang menjadi karyawan tetap disemua perusahaan" \\ "Kita buatkan Homestay agar mereka bisa menginap"}

In the first statement, the word anggaran (budget) has a collocative bond with the word belanja (expenditure), in which the action of the expenditure can be held with the budget. These two words are often used and occured together. Likewise, the word dokter (dokter) and perawat (nurse) are also often used together as the name of professions in health field. While in the third statement, the word karyawan (employee) and perusahaan (company) often appear together in one similar context. They also build a strong collocative bond in that statement. Lastly, the word homestay and menginap (stay) are also used together in the fourth sentence. These two words have a strong relationship, in which the homestay refers to the place for staying, and menginap means the activity of staying.

It can be summed up that all the collocation words used in the speeches are intended to show the collocative bond between each word in the text. In other words, this device indicates the cohesion in the speeches. Even though the collocation is not produced frequently in the three speeches, but it is used properly in the right context. Therefore, they can be well-understood by the audience or the listener.

\section{CONCLUSION}

This study is mainly aimed to identify and to analyze the use of lexical devices in the political speeches of Mayoral election that takes place In Gorontalo city, 2018. There are three speeches of mayor and vice-mayor candidates taken as the source of data. They are transcribed into written forms, then identified and analyzed based on the Halliday and Hasan's theory of lexical cohesion devices (reiteration and collocation).

Nunan (1993, p.28) argues that Lexical cohesion happens when two words in a text are semantically related in some way; in other words, they are related in terms of their meaning. 
Therefore, this study is intended to observe the words as the lexical devices used by the politician in delivering their speech, whether or not they use the word properly, in terms of forms and meanings. The use of two or a group of related words, which are semantically related well and correctly, indicates a good cohesion in a text. This is what this study observes about.

The data analysis reveals that the speeches contain the lexical devices which are used variously, in different purpose and intention. The reiteration and the collocation as the types of lexical devices are found the three speeches. The three types of reiteration; repetition, synonym/near synonym, and superordinate are used by the politician in their speeches. While another type of reiteration; the general word, is not found in the speeches. I assume that, it might be caused by the language that the politians used in delivering their speeches is Indonesian language, so there is not any general word like what Englih has there.

Each of the speaker uses repetition in his speech. Compared to the other candidates, the first speaker from the first candidate produces the repetition many times and frequently. The repetition that they produce have several functions and intentions. For the first candidate, the repetitions are used to confirm about several things which are basically intended to persuade the audience to trust and to choose them as the mayor and the vice-mayor of Gorontalo city. In their speech, the repetition is used as a device to ensure the audience that they will be good leaders, to reveal to the audience the problems and facts faced by the presents government, and to emphasize the programs that they will do if they are choosen as the mayor and the vice-mayor of Gorontalo city.

Whereas, the second candidate uses the repetition as a device to get and to emphasize several things. The first is to catch the audience attention, the second is to build a strong belief in the people's mind that the second candidates are the right figure to lead Gorontalo city ahead, the third is to recall the people's mind about what they have made before as the Mayor and vice-Mayor of Gorontalo city, and the fourth is to give a proof about the problems of city and the solutions that they have made for the problems.

While for the third candidate, the repetition is used to show their thought and opinion about something, to strengthen their opinion, to give a clear description and explanation, and the last is to present a fact or a problem in order that it can be known and understood clearly by the audience.

Furthermore, the synonym and near synonym are also identified in the speeches. The synonym and near synonym are used with various functions and intentions. It functions as a device to make a clarification and emphasis about what the speaker has mentioned or said before, as emphasis of a statement, and an effort to give a clear understanding to the audience about something important, and as a device to emphasize the important point of a statement.

The third type of reiteration identified in the speeches is superordinate. The use of superordinat in each statement of the speakers indicate an effort of the candidate to give clarification about something by mentioning the specific word after mentioning the superordinate word. There is a good semantic relation and continuity in each word that refers to the superordinate.

The collocation as the last type of lexical cohesion is also obtained in the three speeches. All the collocation words used in the speeches are intended to show the collocative bond between each word in the text of the speeches. In other words, this device indicates the cohesion in the speeches. Even though the collocation is not produced frequently in the three speeches, but it is used properly in the right context. Therefore, they can be well-understood by the audience or the listener.

In conclusion, the lexical cohesive devices are used properly in each of the speech. They are succesfully used as the tools to deliver the speakers purposes and intentions. Mostly, it is used to state the facts and opinions, and to persuade the audience to believe that all what they 
said are true, so that the audience can choose them as the leader of Gorontalo city in the election day. The use of lexical devices in the speeches also proves that even a spoken language needs a good cohesion, so that it can be well-accepted and well-understood by the listener.

\section{REFERENCES}

Beard, A. (2000). The Language of Politics. London: Routledge.

Beaugrande, R. de \& W. Dressler. (1981). Introduction to Text Linguistics, London, Longman.

Brown, G \& G Yule. (1983). Discourse Analysis. Cambridge University Press.

Crystal, David. 1995. The Cambridge Encyclopedia of the English Language. Cambridge: Cambridge University Press.

Guo wen, Huang. 2001. The Analysis of The Theory and Prectice: Advertising Discourse research. China: Shanghai foreign press.

Harris, Z. S. (1952). Discourse analysis. Language.

Halliday, M. A. K. \& Hasan, R. (1976). Cohesion in English. London: Longman

Hasan, R. (1984). Coherence and Cohesive Harmony. In J. Flood (Ed.).Understanding Reading Comprehension. Declaware: International Reading Association.

Nunan, David. 1993. Discourse Studies: An Introductory Text-book.

Palmer, Frank Robert. 1981. Semantics. Cambridge: Cambridge University Press.

Pike, Kenneth L. (1954). Language in Relation to a Unified Theory of the Structure of Human Behaviour. Glendale, Calif: Summer Institute of Linguistics.

Taiwo, R. (2009). Legitimization and coercion in political discourse: A case study of olusegun obasanjo address to the PDP elders and stakeholders forum. Journal of Political Discourse Analysis, 2(2), 192. U.S.A. Nova Science Publisher.

Van Dijk, T. A. (1977). Text and Context. London: Longman. 